\title{
Economic Contributions of the Florida Citrus Industry in 2015/16
}

\author{
Christa D. Court, Alan W. Hodges, Mohammad Rahmani, and Thomas H. Spreen²
}

\section{Acknowledgements}

This report was made possible by the support of the Florida Department of Citrus (FDOC), headquartered in Bartow, Florida. Valuable assistance in the preparation of the report was provided by Marisa Zansler, FDOC Director of Economic and Market Research, and Gregory Caudill, FDOC Database Analyst.

Full Report available online at http://fred.ifas.ufl.edu/ economicimpactanalysis/publications/2015-citrus-industry/

\section{Executive Summary}

The Florida citrus industry encompasses a range of economic activities, including fruit production in 27 counties of central and southern Florida; fresh fruit grading, packing, and shipping to domestic and international markets; fruit processing for juice extraction; and juice packaging for retail distribution. Florida citrus-bearing grove area has declined from over 750,000 acres in the year 2000 to around 435,000 acres in 2016, a reduction of 42 percent, while production volume utilized has declined by 68 percent, primarily due to losses from citrus greening disease (also known as Huanglongbing, or HLB), which entered the state in 2005.

The purpose of this study is to estimate the economic contributions of the citrus industry to the state of Florida in fiscal year 2015/16, to update previous studies for 2012/13 and 2014/15, and to update previous estimates for the

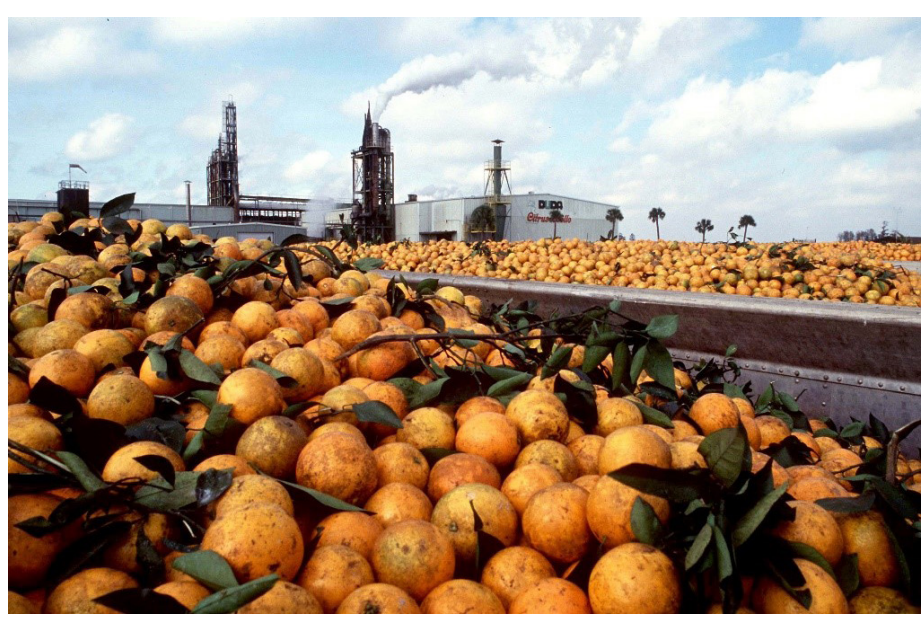

Credit: USDA

economic impacts of citrus greening disease (Hodges and Spreen 2012, 2015). The analysis was conducted using the IMPLAN $^{\circledR}$ regional economic modeling system and associated databases (IMPLAN ${ }^{\circledR}$ Group, LLC) to estimate the broad regional contributions of the industry, including economic multipliers that capture the economic activity generated in other sectors through the industry supply chain and by re-spending of income and government revenues generated from the sale of Florida citrus products.

During the 2015/16 marketing season, 94.2 million boxes of citrus fruit were produced in Florida, including 81.6 million boxes of oranges, 10.8 million boxes of grapefruit, and 1.8 million boxes of specialty citrus, of which 11 percent was sold in the fresh market and 89 percent was used for processing. The total grower value of citrus fruit was over

1. This is EDIS document FE1021, a publication of the Food and Resource Economics Department, UF/IFAS Extension. Published July 2017. Visit the EDIS website at http://edis.ifas.ufl.edu.

2. Christa D. Court, assistant scientist; Alan W. Hodges, extension scientist; Mohammad Rahmani, economic analyst; and Thomas H. Spreen, professor emeritus; Food and Resource Economics Department, UF/IFAS Extension, Gainesville, FL.

The Institute of Food and Agricultural Sciences (IFAS) is an Equal Opportunity Institution authorized to provide research, educational information and other services

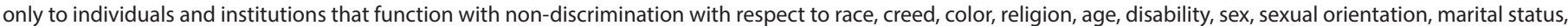

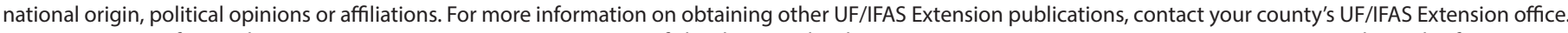
U.S. Department of Agriculture, UF/IFAS Extension Service, University of Florida, IFAS, Florida A \& M University Cooperative Extension Program, and Boards of County Commissioners Cooperating. Nick T. Place, dean for UF/IFAS Extension. 
$\$ 825$ million, with fruit for processing valued at nearly $\$ 656$ million and fruit for fresh consumption valued at nearly $\$ 170$ million, based on delivered prices. Florida citrus juice processors produced 810 million gallons of citrus juice in $2015 / 16$, with a total producer value of $\$ 2.790$ billion (free on board [F.O.B.] price basis). Florida citrus processors also produced byproducts of citrus pulp, meal, molasses, and the essential oil d-Limonene, valued at \$91 million.

The economic contribution analysis estimated total applicable industry output contributions of $\$ 8.632$ billion, including $\$ 2.118$ billion from citrus fruit production, $\$ 6.207$ billion from citrus juice manufacturing, and \$308 million for fresh citrus marketing (Table ES1). The citrus industry supported a total of 45,422 full-time and part-time jobs in the state. Total value added contributions, estimated at $\$ 4.230$ billion, represent the industry's contribution to Gross State Product. Labor income contributions amounted to $\$ 2.559$ billion, representing earnings by employees and business owners. Total state and local tax contributions of the Florida citrus industry were \$271 million.
The southern citrus production area had the highest share of citrus industry employment contributions (13,643 jobs), followed by the western citrus production area $(12,257$ jobs) and the central citrus production area $(11,445)$. Comparing the overall economic contributions of the Florida citrus industry in 2015/16 with the $2012 / 13$ period using updated data, employment declined by 31.6 percent, labor income decreased by 31.1 percent, value added decreased by 31.4 percent, and industry output decreased by 31.0 percent in constant dollar terms.

The economic impacts of citrus greening (HLB) over the period 2012/13 through 2015/16 were estimated at a loss of $\$ 4.393$ billion in cumulative industry output, or an annual average of $\$ 1,098$ million, while total value added and employment supported decreased by an annual average of $\$ 658$ million and 7,945 full-time and part-time jobs, respectively, over this period.

Table ES1. Summary of economic contributions of Florida citrus industry activities, 2015/16

\begin{tabular}{|c|c|c|c|c|c|}
\hline Industry Activity & $\begin{array}{l}\text { Impact Type } \\
\text { (Multiplier) }\end{array}$ & $\begin{array}{c}\text { Employment } \\
\text { (Jobs) }\end{array}$ & $\begin{array}{l}\text { Labor Income } \\
\text { (Million \$) }\end{array}$ & $\begin{array}{l}\text { Value Added } \\
\text { (Million \$) }\end{array}$ & $\begin{array}{l}\text { Industry Output } \\
\text { (Million \$) }\end{array}$ \\
\hline \multirow[t]{4}{*}{ Citrus Fruit Production } & Direct Effect & 4,438 & 289.2 & 447.2 & 824.8 \\
\hline & Indirect Effect & 3,102 & 104.9 & 126.6 & 216.9 \\
\hline & Induced Effect & 8,023 & 408.7 & 688.3 & $1,075.8$ \\
\hline & $\underline{\text { Total Effect }}$ & $\underline{15,563}$ & $\underline{802.8}$ & $\underline{1,262.1}$ & $\underline{2,117.5}$ \\
\hline \multirow[t]{4}{*}{ Citrus Juice Manufacturing } & Direct Effect & 5,505 & 418.0 & 740.9 & $2,881.7$ \\
\hline & Indirect Effect & 5,230 & 339.5 & 553.5 & $1,040.9$ \\
\hline & Induced Effect & 17,137 & 877.7 & $1,467.6$ & $2,283.9$ \\
\hline & $\underline{\text { Total Effect }}$ & $\underline{27,872}$ & $\underline{1,635.2}$ & $\underline{2,762.0}$ & $\underline{6,206.5}$ \\
\hline \multirow[t]{4}{*}{ Fresh Fruit Packinghouses } & Direct Effect & 516 & 43.8 & 80.3 & 114.6 \\
\hline & Indirect Effect & 210 & 11.8 & 18.2 & 29.0 \\
\hline & Induced Effect & 1,261 & 65.1 & 107.1 & 164.9 \\
\hline & $\underline{\text { Total Effect }}$ & $\underline{1,987}$ & $\underline{120.7}$ & $\underline{205.6}$ & $\underline{308.4}$ \\
\hline \multirow[t]{4}{*}{ Total All Activities } & Direct Effect & 10,460 & 751.1 & $1,268.4$ & $3,821.0$ \\
\hline & Indirect Effect & 8,542 & 456.2 & 698.2 & $1,286.8$ \\
\hline & Induced Effect & 26,420 & $1,351.5$ & $2,263.0$ & $3,524.6$ \\
\hline & $\underline{\text { Total Effect }}$ & $\underline{45,422}$ & $\underline{2,558.8}$ & $\underline{4,229.7}$ & $\underline{8,632.4}$ \\
\hline \multicolumn{6}{|c|}{$\begin{array}{l}\text { Note: Total applicable contributions for all activities include direct, indirect, and induced multiplier effects for out-of-state sales and direct } \\
\text { multiplier effects only for in-state sales. Values in } 2016 \text { US dollars. Employment includes full-time and part-time jobs. Numbers may not sum } \\
\text { due to rounding. } \\
\text { Source: IMPLAN }{ }^{\circledR} \text { software and } 2012 \text { region data for Florida (IMPLAN }{ }^{\circledR} \text { Group LLC). }\end{array}$} \\
\hline
\end{tabular}

